\title{
Hypoglycaemic potentials of frog oil in alloxan-induced diabetic rats
}

\author{
Osheke Shekins Okere ${ }^{1}$, Moses Dele Adams ${ }^{1,}$, Uju Dorathy Ejike ${ }^{1}$, Eunice Ogunwole², \\ Ejike Daniel Eze ${ }^{2}$ \\ ${ }^{1}$ Department of Biochemistry, Faculty of Science and Technology, Bingham University, Karu, Nasarawa State, Nigeria \\ ${ }^{2}$ Department of Physiology, Faculty of Basic Medical Sciences, Bingham University, Karu, Nasarawa State, Nigeria
}

\section{Email address:}

mdadamsonline@yahoo.com (M. D. Adams)

\section{To cite this article:}

Osheke Shekins Okere, Moses Dele Adams, Uju Dorathy Ejike, Eunice Ogunwole, Ejike Daniel Eze. Hypoglycaemic Potentials of Frog oil in Alloxan-Induced Diabetic Rats. American Journal of BioScience. Vol. 2, No. 4, 2014, pp. 115-121.

doi: $10.11648 /$ j.ajbio.20140204.12

\begin{abstract}
The hypoglycaemic potentials of frog oil in alloxan-induced diabetic rats were investigated. Thirty six male albino rats weighing $120.47 \pm 2.52 \mathrm{~g}$ was completely randomized into six groups (A-F) comprising 6 animals each. Animals in group A (control) were administered $1 \mathrm{ml}$ of distilled water while those in groups B, C, D, E and F were induced with diabetes mellitus by intraperitoneal administration of alloxan monohydrate $(180 \mathrm{mg} / \mathrm{kg}$ body weight) and in addition were respectively administered distilled water, metformin (a reference antidiabetic drug), 3, 6 and $9 \mathrm{mg} / \mathrm{kg}$ body weight of frog oil once daily. Treatment with the oil lasted for 14 days during which blood glucose level and selected biochemical parameters were determined. The results showed that there was significant $(\mathrm{p}<0.05)$ reduction in glucose levels in the group treated with $9.0 \mathrm{mg} / \mathrm{kg}$ body weight of the oil from $221.22 \pm 0.15$ to $100.15 \pm 0.07 \mathrm{mg} / \mathrm{dl}$, indicating the best antidiabetic activity of all the treatment groups. The oil also caused significant $(p<0.05)$ decrease in serum total bilirubin levels from $8.73 \pm 0.07 \mu \mathrm{mol} / \mathrm{L}$ to $2.43 \pm 0.03 \mu \mathrm{mol} / \mathrm{L}$; serum total cholesterol levels from $313.48 \pm 0.05 \mathrm{mmol} / \mathrm{L}$ to $232.40 \pm 0.19 \mathrm{mmol} / \mathrm{L}$; liver aspartate aminotransferase (AST) activity from $76.93 \pm 0.02 \mathrm{U} / \mathrm{L}$ to $35.25 \pm 0.02 \mathrm{U} / \mathrm{L}$; liver alanine aminotransferase (ALT) activity from $85.52 \pm 0.05 \mathrm{U} / \mathrm{L}$ to $39.71 \pm 0.08 \mathrm{U} / \mathrm{L}$ respectively. Overall, these findings established the fact that frog oil has hypoglycaemic potentials and thus can be recommended for use in the treatment of diabetes. The results from biochemical parameters indicated that frog oil could also be explored in the control of some of the metabolic dysfunctions normally associated with diabetes.
\end{abstract}

Keywords: Hypoglycaemic Potentials, Frog Oil, Alloxan, Diabetes Mellitus, Metformin, Blood Glucose

\section{Introduction}

Frogs are classified as Amphibians. Amphibians are essentially a tropical group and well represented in Nigeria [32]. They are the first group of vertebrate animals to make a serious attempt at life on land. Their history is long and complex. Few people realize how ancient frogs are. For over 190 years, the ancestors of modern frogs have roamed (if not rule) the earth looking much the same as they do today. The secret of their success is their amazing adaptability [2]. They can in general move, feed, and breath equally well on land and in fresh water; but nearly all Amphibians return to water to breed. Like all Amphibians, frogs are cold-blooded, meaning that their body temperature changes with the temperature of the environment. When temperature drops, some frogs dig and burrow underground or in the mud at the bottom of ponds [21]. Frogs like to be near ponds which have plenty of algae and plants near the edge usually with shallow edges, so that they can easily climb out. In general, the common frog seems to prefer ponds which have water flowing in and out of them [15].

Diabetes mellitus is a chronic disorder of carbohydrate, lipid, and protein metabolism characterized by persistent elevation of fasting blood glucose above $200 \mathrm{mg} / \mathrm{dl}$, due to insufficient or complete cessation of insulin synthesis or secretion and/or peripheral resistance to insulin action [17, 29]. The disorder is associated with increased risk of blindness, stroke, heart and blood vessel disease, kidney failure, retinopathy, amputation, neuropathy, ulceration, 
nerve damage and gangrene of extremities [27, 35]. Diabetes mellitus is a growing public health concern worldwide causing severe and costly complications [26]. Over 173 million people are suffering from diabetes mellitus in the world and this figure is likely to be increased to 300 million or more by the year 2025 [18]. The global incidence of diabetes mellitus for all age groups was estimated to be $2.8 \%$ in 2000 and the estimate will reach $4.4 \%$ in 2030 [36]. Type 1 diabetes results from the body's failure to produce insulin [40]. Presently, almost all persons with Type 1 diabetes must take insulin injections [40, 42]. Type 2 diabetes results from insulin resistance, a condition in which cells fail to use insulin properly, sometimes combined with relative insulin deficiency $[6,41]$.

Previous studies by [9] have reported the purification of frog oil using animal-bone activated carbon while [25] worked on evaluation of the antimicrobial activities and chemical composition of body fat from Amphibians Leptodactylus macrosternum Miranda-Ribeiro (1926) and Leptodactylus vastus Adolf-Lutz (1930) in North Brazil. All this was without report on the hypoglycaemic potentials of the oil, therefore creating room for further studies. Also, frog oil has been claimed by traditional healers to possess hypoglycaemic effects, though it has not been an area of extensive research [38], which would provide scientific evidence to either substantiate or refute the purported claim. Therefore, this study was designed to evaluate the hypoglycaemic potentials of frog oil using alloxan-induced diabetic rats as model.

\section{Materials and Methodology}

\subsection{Materials}

\subsubsection{Experimental Animals}

Male albino rats (Rattus norvegicus) weighing $120.47 \pm 2.52 \mathrm{~g}$ were obtained from the animal house of National Veterinary Research Institute, VOM, Jos, Plateau State, Nigeria. This was used for both the hypoglycaemic and toxicity study.

\subsubsection{Assay Kits and Drugs}

The assay kits for the determination of AST and ALT were products of Randox Laboratory Ltd, Co-Atrim, UK. Alloxan monohydrate (1, 3-Diazinane-2, 4, 5, 6- tetrone) and metformin were products of Kemei Laboratories Ltd., Mumbai, India and May and Bayer Ltd., Dagenham, England respectively. Other reagents used were of analytical grade and were prepared with distilled water unless otherwise stated.

\subsubsection{Glucose Meter and Test Strips}

One Touch Blood Glucose Monitoring System (glucometer) and On-Call-Redi Blood Glucose Test Strips were products of Schiffgraben Diagnostic, Hannover, Germany and Acon Laboratories Inc., San Diego, USA respectively.

\subsection{Methodology}

\subsubsection{Extraction of Frog Oil}

Fat tissues were removed from the frog and rinsed with water. The fat tissues were then heated in a clean plate, until the oil was extracted and collected in large quantities.

\subsubsection{Determination of Blood Glucose and Induction of Diabetes}

After 14-16 hours of over-night fasting, the fasting blood glucose was determined by drawing blood samples $(0.6 \mu \mathrm{L})$ from the sharply cut tail vein, placing it on the test strip that had been inserted into the glucometer. Thereafter, diabetes mellitus was induced intraperitoneally in the experimental rats by the administration of diabetogenic dose of alloxan monohydrate $(180 \mathrm{mg} / \mathrm{kg}$ body weight). Alloxan crystals weighing $1.2 \mathrm{~g}$ were dissolved in $10 \mathrm{ml}$ normal saline to give $12 \mathrm{mg} / \mathrm{ml}$ solution. Then $0.3 \mathrm{ml}$ of the alloxan solution was administered as the diabetogenic dose following the methods described by $[5,13]$. Only animals with fasting blood glucose level higher than $200.00 \mathrm{mg} / \mathrm{dL}$ were used for the study.

\subsubsection{Experimental Design}

Thirty six male albino rats weighing $120.47 \pm 2.52 \mathrm{~g}$ was completely randomized into six groups (A-F) comprising 6 animals each. Animals in group A which served as the normal control were administered $1 \mathrm{ml}$ of distilled water. Animals in groups B, C, D, E and F which were all induced with diabetes mellitus by intraperitoneal administration of alloxan monohydrate $(180 \mathrm{mg} / \mathrm{kg}$ body weight) were in addition respectively administered distilled water, metformin (a reference antidiabetic drug), 3, 6 and $9 \mathrm{mg} / \mathrm{kg}$ body weight of the frog oil once daily. Hyperglycemia was confirmed 48 hours after induction using one touch glucometer before treatment with the oil commenced. Treatment with the oil lasted for 14 days during which blood glucose level and selected biochemical parameters were determined.

\subsubsection{Treatment of Experimental Animals}

The animals were allowed to acclimatize for two weeks prior to commencement of the experiment. The animals were allowed free access to rat pellets (Premier Feed Mill Co. Ltd., Ibadan, Nigeria) and tap water ad libitum, and were also administered frog oil, with respect to the experimental design. The amount of oil administered to the rats was based on the work of [14] where the treatment was for 14 days using a metal oropharyngeal cannula. The animals were handled humanely in accordance with the guidelines of European convention for the protection of vertebrate animals and other scientific purposes- ETS-123 [10].

\subsubsection{Collection of Blood, Preparation of Serum and Tissue Homogenate}

Under ether anaesthesia, the veins after being slightly displaced (to prevent blood contamination by interstitial fluid) were cut with a sterile scapel blade and $5 \mathrm{ml}$ of the 
blood was collected into clean and dry centrifuge tubes. The blood was then left undisturbed for 10 minutes at room temperature to clot. The tubes were thereafter centrifuged at 224 g x 10 minutes using Uniscope Laboratory Centrifuge (Model 800D, New Life Medical Instrument, England). The sera were later aspirated with Pasteur pipettes into dry sample bottles and used within 12 hours of preparation for the biochemical assays. The animals were thereafter quickly dissected and the liver was removed. The organ was later blotted with a clean tissue paper, weighed and homogenized in $0.25 \mathrm{M}$ sucrose solution $(1: 5 \mathrm{w} / \mathrm{v})$. The homogenate was then centrifuged at $1340 \mathrm{x} \mathrm{g}$ for 15 minutes. The supernatant was frozen overnight [30] before being used for the determination of selected biochemical parameters.

\subsubsection{Determination of Serum Total Bilirubin}

The method of [23] was selected for modification, as it was the simplest available and most suited for this purpose.

Procedure: Into a test tube containing $2.9 \mathrm{ml}$ of distilled water, $0.1 \mathrm{ml}$ of serum or plasma is added, followed by 0.5 $\mathrm{ml}$ of freshly prepared "diazo" reagent, and finally by 2.5 $\mathrm{ml}$ of absolute methyl alcohol. The contents of the tube are then mixed and allowed to stand at room temperature for 30 minutes before determining the optical density in a standard photoelectric instrument, at a wavelength of $520 \mathrm{~nm}$ (Ilford green filter 624 is satisfactory), distilled water being used for zero setting.

The bilirubin concentration was then determined by reference to a calibration curve or by direct comparison with the artificial standard. Calculation formula using artificial standard is shown below:

$$
\text { Bilirubin }(\mu \mathrm{mol} / \mathrm{L})=\frac{\text { Reading of Sample }}{\text { Reading of Standard }} \times 8.5
$$

\subsubsection{Determination of Serum Total Cholesterol}

Total cholesterol was determined in the serum of the animals by adopting the procedure described by [1]

Principle: Cholesterol reacts with concentrated acid as a typical alcohol to produce coloured substance. In this method, acetic acid and acetic anhydride were used as solvents and dehydrating reagents. Concentrated sulphuric acid was employed as a dehydrating and oxidising agent. The absorbance of the final bluish- green colour obtained was read at $570 \mathrm{~nm}$.

Procedure: Blood samples $(3 \mathrm{ml})$ were collected into a plain container with the aid of a syringe $(2 \mathrm{ml})$ from the heart having anaesthetized pinned and dissected the experimental rat under study on a dissecting-board. The blood sample was allowed to clot before it was centrifuge to obtain blood serum. Five test tubes were labelled; sample, standard and blank. To each of these test tubes was added $0.2 \mathrm{ml}$ of serum, cholesterol standard and distilled water respectively. Thereafter, $5.0 \mathrm{ml}$ acetic acid-acetic anhydride reagent was added to each of the test tubes and the solution were thoroughly mixed, and then allowed to stand for a period of 5 minutes. Then, $0.1 \mathrm{ml}$ of concentrated sulphuric acid was added alongside to each of the tubes, mixed thoroughly and kept in cold water for a period of 10 minutes. The absorbance was then read against the blank. Concentration of the test sample was calculated, using the colorimetric equation:

$$
\text { Cholesterol Conc. }(\mathrm{mmol} / \mathrm{L})=\frac{\mathrm{A}_{\mathrm{s} \text { ample }}}{\mathrm{A}_{\mathrm{s} \text { ample }}} \times \text { Conc. of Standard }
$$

\subsubsection{Estimation of Liver Aspartate Aminotransferase (AST) and Alanine Amino Transaferase (ALT)}

Principle: Enzymes; aspartate aminotransferase (AST) and alanine aminotransferase (ALT) act on the appropriate substance to yield the products oxaloacetate and pyruvate respectively. The ketoacids (oxaloacetate and pyruvate) were assayed colorimetrically coupling with 2, 4dinitrophenyl hydrazine in an alkaline medium to yield the corresponding hydrazones. Liver enzyme activity was done using the assay kits stated above.

\subsubsection{Statistical Analysis}

Results were expressed as the mean \pm SEM of six determinations. The data were analyzed using Duncan Multiple Range Test and complemented with Student's ttest. The differences were considered statistically significant at $\mathrm{p}<0.05$. All the analyses were done using SPSS version 17.0 software (SPSS Inc., Chicago, IL, USA).

\section{Results}

The results showed that all the animals treated with 180 $\mathrm{mg} / \mathrm{kg}$ body weight of alloxan became diabetic after 48 hours with blood glucose level ranging from $219.34 \pm 0.10-$ $276.63 \pm 0.07 \mathrm{mg} / \mathrm{dL}$ (Table 1). The fasting blood glucose level of the animals administered with alloxan and distilled water significantly $(\mathrm{p}<0.05)$ increased from $273.69 \pm 0.09$ to $298.22 \pm 0.78 \mathrm{mg} / \mathrm{dL}$. Administration of the oil at the doses of 3,6 and $9 \mathrm{mg} / \mathrm{kg}$ body weight significantly $(\mathrm{p}<0.05)$ reduced the blood glucose levels progressively up till the end of the treatment period. At day 14, the reduction in the fasting blood glucose of animals administered $9 \mathrm{mg} / \mathrm{kg}$ body weight of the oil produced values that compared well ( $>0.05$ ) with the positive control by the end of the treatment period. In contrast, the fasting blood glucose level of alloxanized diabetic animals treated with 3 and 6 $\mathrm{mg} / \mathrm{kg}$ body weight of the oil, although, reduced, did not compare well with the negative control animals (Table 1).

After 14 days of administration of $9 \mathrm{mg} / \mathrm{kg}$ of frog oil, the concentration of serum total bilirubin significantly $(\mathrm{p}<0.05)$ reduced from $8.73 \pm 0.07 \mu \mathrm{mol} / \mathrm{L}$ to $2.43 \pm 0.03$ $\mu \mathrm{mol} / \mathrm{L}$ (Table 2). 
Table 1. Effect of frog oil administration on the blood glucose level ( $\mathrm{mg} / \mathrm{dL}$ ) in alloxan-induced diabetic rats

\begin{tabular}{llll}
\hline & \multicolumn{2}{l}{ Days after administration of alloxan } & Day 14 \\
\hline Treatment groups & Day 1 & Day 7 & $70.46 \pm 0.22^{\mathrm{a}}$ \\
\hline Control & $74.02 \pm 0.45^{\mathrm{a}}$ & $62.33 \pm 0.23^{\mathrm{b}}$ & $298.22 \pm 0.78^{\mathrm{c}}$ \\
Diabetic rats + Distilled water & $273.69 \pm 0.09^{\mathrm{a}}$ & $286.61 \pm 0.31^{\mathrm{b}}$ & $101.57 \pm 0.14^{\mathrm{c}}$ \\
Diabetic rats + Metformin & $276.63 \pm 0.07^{\mathrm{a}}$ & $121.40 \pm 0.02^{\mathrm{b}}$ & $154.65 \pm 0.06^{\mathrm{c}}$ \\
Diabetic rats + $3 \mathrm{mg} / \mathrm{kg}$ body weight of the oil & $225.20 \pm 0.11^{\mathrm{a}}$ & $194.57 \pm 0.04^{\mathrm{b}}$ & $132.41 \pm 0.41^{\mathrm{c}}$ \\
Diabetic rats $+6 \mathrm{mg} / \mathrm{kg}$ body weight of the oil & $219.34 \pm 0.10^{\mathrm{a}}$ & $177.74 \pm 0.02^{\mathrm{b}}$ & $100.23 \pm 0.07^{\mathrm{c}}$ \\
\hline Diabetic rats $+9 \mathrm{mg} / \mathrm{kg}$ body weight of the oil & $221.22 \pm 0.15^{\mathrm{a}}$ & $160.65 \pm 0.07^{\mathrm{b}}$ & \\
\hline
\end{tabular}

$\mathrm{n}=6 \pm \mathrm{SEM} ;$

${ }^{\mathrm{a}-\mathrm{c}}$ Values carrying superscript different from their respective control for each day are significantly different $(\mathrm{p}<0.05)$.

Table 2. Effect of frog oil administration on serum total bilirubin concentration $(\mu \mathrm{mol} / L)$ in alloxan-induced diabetic rats

\begin{tabular}{llll}
\hline & \multicolumn{2}{l}{ Days after administration of alloxan } & Day 14 \\
\hline Treatment groups & Day 1 & Day 7 & $0.66 \pm 0.01^{\mathrm{a}}$ \\
\hline Control & $0.61 \pm 0.01^{\mathrm{a}}$ & $0.74 \pm 0.01^{\mathrm{a}}$ & $5.72 \pm 0.04^{\mathrm{a}}$ \\
Diabetic rats + Distilled water & $6.36 \pm 0.13^{\mathrm{a}}$ & $6.05 \pm 0.02^{\mathrm{a}}$ & $1.54 \pm 0.05^{\mathrm{b}}$ \\
Diabetic rats + Metformin & $6.65 \pm 0.01^{\mathrm{a}}$ & $3.85 \pm 0.02^{\mathrm{b}}$ & $5.35 \pm 0.02^{\mathrm{a}}$ \\
Diabetic rats + $3 \mathrm{mg} / \mathrm{kg}$ body weight of the oil & $6.86 \pm 0.02^{\mathrm{a}}$ & $6.15 \pm 0.02^{\mathrm{a}}$ & $5.12 \pm 0.02^{\mathrm{a}}$ \\
Diabetic rats $+6 \mathrm{mg} / \mathrm{kg}$ body weight of the oil & $6.88 \pm 0.10^{\mathrm{a}}$ & $5.89 \pm 0.09^{\mathrm{a}}$ & $2.43 \pm 0.03^{\mathrm{b}}$ \\
\hline Diabetic rats $+9 \mathrm{mg} / \mathrm{kg}$ body weight of the oil & $8.73 \pm 0.07^{\mathrm{a}}$ & $5.66 \pm 0.01^{\mathrm{a}}$ & 2 \\
\hline
\end{tabular}

$\mathrm{n}=6 \pm \mathrm{SEM}$;

${ }^{a-b}$ Values carrying superscript different from their respective control for each day are significantly different $(\mathrm{p}<0.05)$.

After 14 days of administration of $9 \mathrm{mg} / \mathrm{kg}$ of frog oil, $\quad$ reduced from $313.48 \pm 0.05 \mathrm{mmol} / \mathrm{L}$ to $232.40 \pm 0.19 \mathrm{mmol} / \mathrm{L}$ the serum total cholesterol level significantly $(\mathrm{p}<0.05) \quad$ (Table 3$)$.

Table 3. Effect of frog oil administration on serum total cholesterol concentration (mmol/L) in alloxan-induced diabetic rats

\begin{tabular}{llll}
\hline & \multicolumn{2}{l}{ Days after administration of alloxan } & Day 14 \\
\hline Treatment groups & Day 1 & Day 7 & $124.48 \pm 0.10^{\mathrm{a}}$ \\
\hline Control & $125.11 \pm 0.16^{\mathrm{a}}$ & $121.11 \pm 0.13^{\mathrm{a}}$ & $329.31 \pm 0.08^{\mathrm{c}}$ \\
Diabetic rats + Distilled water & $303.94 \pm 0.19^{\mathrm{a}}$ & $316.19 \pm 0.18^{\mathrm{b}}$ & $132.17 \pm 0.13^{\mathrm{c}}$ \\
Diabetic rats + Metformin & $294.28 \pm 0.15^{\mathrm{a}}$ & $271.16 \pm 0.14^{\mathrm{b}}$ & $267.49 \pm 0.15^{\mathrm{c}}$ \\
Diabetic rats + $\mathrm{mg} / \mathrm{kg}$ body weight of the oil & $299.43 \pm 0.09^{\mathrm{a}}$ & $284.36 \pm 0.06^{\mathrm{b}}$ & $259.49 \pm 0.20^{\mathrm{c}}$ \\
Diabetic rats + $\mathrm{mg} / \mathrm{kg}$ body weight of the oil & $305.18 \pm 0.10^{\mathrm{a}}$ & $278.54 \pm 0.94^{\mathrm{b}}$ & $232.40 \pm 0.19^{\mathrm{c}}$ \\
\hline Diabetic rats + 9 mg/kg body weight of the oil & $313.48 \pm 0.05^{\mathrm{a}}$ & $269.30 \pm 0.15^{\mathrm{b}}$ & \\
\hline
\end{tabular}

$\mathrm{n}=6 \pm \mathrm{SEM}$

${ }^{\mathrm{a}-\mathrm{c}}$ Values carrying superscript different from their respective control for each day are significantly different $(\mathrm{p}<0.05)$.

After 14 days of administration of $9 \mathrm{mg} / \mathrm{kg}$ of the oil, liver aspartate aminotransferase (AST) from $76.93 \pm 0.02$ there was a significant $(\mathrm{p}<0.05)$ decrease in the activity of $\mathrm{U} / \mathrm{L}$ to $35.25 \pm 0.02 \mathrm{U} / \mathrm{L}$ (Table 4 ).

Table 4. Effect of frog oil administration on liver aspartate aminotransferase activity $(U / L)$ in alloxan-induced diabetic rats

\begin{tabular}{llll}
\hline & \multicolumn{2}{l}{ Days after administration of alloxan } & Day 14 \\
\hline Treatment groups & Day 1 & Day 7 & $17.45 \pm 0.02^{\mathrm{a}}$ \\
\hline Control & $17.69 \pm 0.16^{\mathrm{a}}$ & $15.73 \pm 0.03^{\mathrm{a}}$ & $74.55 \pm 0.02^{\mathrm{a}}$ \\
Diabetic rats + Distilled water & $73.93 \pm 0.02^{\mathrm{a}}$ & $75.33 \pm 0.02^{\mathrm{a}}$ & $19.14 \pm 0.02^{\mathrm{c}}$ \\
Diabetic rats + Metformin & $75.36 \pm 0.19^{\mathrm{a}}$ & $46.64 \pm 0.02^{\mathrm{b}}$ & $52.96 \pm 0.02^{\mathrm{c}}$ \\
Diabetic rats + 3 mg/kg body weight of the oil & $78.53 \pm 0.09^{\mathrm{a}}$ & $69.73 \pm 0.02^{\mathrm{b}}$ & $47.75 \pm 0.02^{\mathrm{c}}$ \\
Diabetic rats + 6 mg/kg body weight of the oil & $76.35 \pm 0.03^{\mathrm{a}}$ & $62.54 \pm 0.03^{\mathrm{b}}$ & $35.25 \pm 0.02^{\mathrm{c}}$ \\
\hline Diabetic rats + 9 mg/kg body weight of the oil & $76.93 \pm 0.02^{\mathrm{a}}$ & $58.93 \pm 0.02^{\mathrm{b}}$ & \\
\hline
\end{tabular}

$\mathrm{n}=6 \pm$ SEM;

${ }^{\mathrm{a}-\mathrm{c}}$ Values carrying superscript different from their respective control for each day are significantly different $(\mathrm{p}<0.05)$. 
After 14 days of administration of $9 \mathrm{mg} / \mathrm{kg}$ of frog oil, there was a significant $(\mathrm{p}<0.05)$ decrease in the activity of liver alanine aminotransferase (ALT) from $85.52 \pm 0.05 \mathrm{U} / \mathrm{L}$ to $39.71 \pm 0.08 \mathrm{U} / \mathrm{L}$ (Table 5).

Table 5. Effect of frog oil administration on liver alanine aminotransferase activity (U/L) in alloxan-induced diabetic rats

\begin{tabular}{|c|c|c|c|}
\hline \multirow[b]{2}{*}{ Treatment groups } & \multicolumn{3}{|c|}{ Days after administration of alloxan } \\
\hline & Day 1 & Day 7 & Day 14 \\
\hline Control & $21.31 \pm 0.10^{\mathrm{a}}$ & $21.80 \pm 0.08^{\mathrm{a}}$ & $23.57 \pm 0.07^{\mathrm{a}}$ \\
\hline Diabetic rats + Distilled water & $86.61 \pm 0.14^{\mathrm{a}}$ & $87.73 \pm 0.13^{\mathrm{a}}$ & $88.42 \pm 0.10^{\mathrm{a}}$ \\
\hline Diabetic rats + Metformin & $84.40 \pm 0.29^{\mathrm{a}}$ & $50.21 \pm 0.06^{\mathrm{b}}$ & $23.58 \pm 0.13^{\mathrm{c}}$ \\
\hline Diabetic rats $+3 \mathrm{mg} / \mathrm{kg}$ body weight of the oil & $80.66 \pm 0.13^{\mathrm{a}}$ & $79.43 \pm 0.10^{\mathrm{b}}$ & $71.31 \pm 0.08^{\mathrm{c}}$ \\
\hline Diabetic rats $+6 \mathrm{mg} / \mathrm{kg}$ body weight of the oil & $89.38 \pm 0.16^{\mathrm{a}}$ & $87.23 \pm 0.07^{\mathrm{b}}$ & $51.70 \pm 0.15^{\mathrm{c}}$ \\
\hline Diabetic rats $+9 \mathrm{mg} / \mathrm{kg}$ body weight of the oil & $85.52 \pm 0.05^{\mathrm{a}}$ & $82.29 \pm 0.03^{\mathrm{b}}$ & $39.71 \pm 0.08^{\mathrm{c}}$ \\
\hline
\end{tabular}

$\mathrm{n}=6 \pm \mathrm{SEM}$

${ }^{\mathrm{a}-\mathrm{c}}$ Values carrying superscript different from their respective control for each day are significantly different $(\mathrm{p}<0.05)$.

\section{Discussion}

Diabetes mellitus is a chronic disorder of carbohydrate, fat and protein metabolism caused by either lack of insulin secretion or decreased sensitivity of the tissues to insulin $[16,34]$. Diabetic individuals are at high risk of developing common metabolic complications which result in morbidity and mortality [39]. Alloxan, a beta cytotoxin, destroys $\beta$ cells of islets of Langerhans of pancreas resulting in a decrease in endogenous insulin secretion and paves ways for the decreased utilization of glucose by body tissues [43]. It results in elevation of blood glucose level, decreased protein content, increased levels of serum cholesterol and triacylglycerols [8]. Therefore, the determination of concentration of glucose content in the blood of diabetic laboratory animals induced with alloxan is a useful quantitative index of diabetes. On the other hand, the reference antidiabetic drug, metformin, is a commonly used anti-hyperglycaemic agent which acts via several mechanisms such as increasing insulin binding in various cell types, effects on intestinal glucose absorption, insulin secretion, and hepatic glucose production. In vivo and in vitro studies have demonstrated that metformin stimulates the insulin-induced component of glucose uptake into skeletal muscle and adipocytes in both diabetic individuals and animal models [19]. Frog oil caused a significant decrease in the blood glucose level of the experimental rats after oral administration for 14days. The potency was measured in terms of the level of reduction in glucose level after 14 days of administration of the oil to the rats. According to [28], the major goal of treating diabetes mellitus is controlling elevated blood sugars without causing abnormally low levels of blood sugar. As seen in Table 1, the oil was able to decrease the glucose level from $221.22 \pm 0.15 \mathrm{mg} / \mathrm{dL}$ to $100.23 \pm 0.07 \mathrm{mg} / \mathrm{dL}$ without causing hypoglycaemia. Although, the other dose levels of frog oil also produced antidiabetic activity, the most effective was at highest dose of $9 \mathrm{mg} / \mathrm{kg}$ body weight investigated in the present study.

Bilirubin is created by the activity of biliverdin reductase on biliverdin, a green tetrapyrrolic bile pigment that is also a product of heme catabolism [2]. In the liver, bilirubin can either be conjugated or unconjugated. Erythrocytes (red blood cells) generated in the bone marrow are disposed off in the spleen when they get old or damaged. This releases hemoglobin, which is broken down to heme as the globin parts are turned into amino acids. The heme is then turned into unconjugated bilirubin in the reticuloendothelial cells of the spleen. This unconjugated bilirubin is not soluble in water. It is then bound to albumin and sent to the liver under normal conditions. In the liver, it can be conjugated with glucuronic acid by the enzyme glucuronyltransferase, making it soluble in water. Much of it goes into the bile and thus out into the small intestine. Some of the conjugated bilirubin remains in the large intestine and is metabolized by colonic bacteria to urobilinogen, which is further metabolized to stercobilinogen, and finally oxidized to stercobilin. This stercobilin gives faeces its brown colour. Some of the urobilinogens are reabsorbed and excreted in the urine along with an oxidized form, urobilin. These occur under normal conditions but when the liver is damaged, the unconjugated bilirubin will accumulate in the blood while conjugated bilirubin will accumulate in the urine [33]. Alloxan induced- diabetes has been shown to lead to hepatocellular damage. This explains why the level of bilirubin was elevated after induction with alloxan. After administration of frog oil for 14 days, it was observed that there was a significant decrease in the level of serum total bilirubin from $8.73 \pm 0.07 \mu \mathrm{mol} / \mathrm{L}$ to $2.43 \pm 0.03$ $\mu \mathrm{mol} / \mathrm{L}$ (Table 2). This shows that the oil was able to prevent further damage of the liver thus making it possible for bilirubin to be stored in the liver. Also, elevated serum bilirubin has been associated with haemolytic anaemia which is an iron deficiency that occurs when the rate of breakdown of $\mathrm{RBC}$ exceed the rate of production of $\mathrm{RBC}$ leading to insufficient iron supply. Frog oil is a rich source of iron thus in the case of haemolytic anaemia will replenish the iron used in $\mathrm{RBC}$ production, thus reducing the level of bilirubin in the serum [4].

Alloxan-induced diabetes leads to an elevation in the serum total cholesterol level to $329.31 \pm 0.08 \mathrm{mmol} / \mathrm{L}$ (Table 3), a condition known as hypercholesterolemia. This occurred due to an increase in the cholesterogenesis in the 
alloxan-induced diabetic rat. High cholesterol level in the blood is associated with atherosclerosis which leads to clogging of the blood vessels and increases diabetes, stroke and other cardiovascular diseases [12]. During diabetic conditions, the level of HDL is reduced while that of triglyceride, VLDL and LDL are increased [11]. This is very bad for the body because the later carries cholesterol from the liver to other cells which leads to an increase in the cholesterol level in the body while the former reduces the level of cholesterol by collecting cholesterol from the body and taking it to the liver for synthesis [22].

Administration of frog oil led to a decrease in the VLDL and LDL level and an increase in the HDL which in turn lead to a significant decrease in the serum total cholesterol level of the experimental rat to $232.40 \pm 0.19 \mathrm{mmol} / \mathrm{L}$ (Table 3 ). From the fatty acid analysis carried out, it showed that the oil is a monounsaturated fatty acid and it has been established that foods containing monounsaturated fats reduce low-density lipoprotein (LDL) cholesterol, while possibly increasing high-density lipoprotein (HDL) cholesterol. The oil also contains polyunsaturated fatty acids which are good sources of Omega-3 and Omega- 6 fatty acids which are known to help lower the risk of chronic diseases such as heart disease, stroke, and cancer, as well as lower LDL or "bad" cholesterol [20, 24]. From the analysis, although the administration of frog oil showed significant effect between day 1 and day 14, the oil will require prolong usage for maximum activity to be felt.

The aminotransferases, AST and ALT, are called marker enzymes because they can be used in clinical diagnosis to indicate liver or sometimes heart damage/injury [7, 37]. The aminotransferases are involved in the transfer of amino group from $\alpha$-amino to $\alpha$-keto acids and in the biochemical regulation of intracellular amino acid pool. After the induction of the rats using alloxan, there was a significant increase above normal in the level of these liver enzymes. Studies show the relationship between hepatocellular damage and diabetics, which results in the leakage of these enzymes into the serum as observed. Administration of the oil reduced cell membrane damage thus decreasing the activity of the liver enzymes from $76.93 \pm 0.02 \mathrm{U} / \mathrm{L}$ to $35.25 \pm 0.02 \mathrm{U} / \mathrm{L}$ in AST and $85.52 \pm 0.05 \mathrm{U} / \mathrm{L}$ to $39.71 \pm 0.08$ $\mathrm{U} / \mathrm{L}$ in ALT (Tables 4 and 5). A similar finding on liver AST and ALT activity was reported by [31]. The liver is the site for metabolic action in the body. In type 2 diabetes where the activity and concentration of the liver is reduced, the excess glucose in the liver will not be stored as glycogen instead they remain as glucose and are latter converted to fatty acid leading to a condition known as non-alcoholic fatty liver, a condition which damage the liver by leading to inflammation of the liver and leakage of liver enzymes into the serum.

\section{Conclusion}

The significant reduction in elevated blood glucose level by the frog oil at all doses indicates anti-hyperglycaemic activity of the oil. The best antidiabetic activity was obtained with the $9 \mathrm{mg} / \mathrm{kg}$ body weight of the oil. The oil may also be helpful to patients in controlling certain complications associated with diabetes. As a result of the global concern over rising cases of Type 1 and Type 2 diabetes, and the exorbitant nature of their current therapeutic regimen, the findings from the present study portend a huge sigh of relief to the silent millions of people whose lifespan could be extended by living healthier lives at little or no cost, if they adopt the recommendations of this noble research work.

\section{Acknowledgement}

We acknowledge the contributions of technologists: Mr. Raymond Jonathan and Miss Victoria Olomi-ojo, from the Department of Biochemistry, Bingham University, Karu, Nasarawa State, Nigeria.

\section{References}

[1] Allan CD, and Peter JGD, Enzymic Assay of Total Cholesterol Involving Chemical or Enzymic Hydrolysis. A Comparison of Methods. Clin. Chem. 1979; 25/6, 976-984.

[2] Baranano SM, Balady GJ, and Criqui MH, "Primary prevention of coronary heart disease: guidance from Framingham: a statement for healthcare professionals from the AHA Task Force on Risk Reduction. American Heart Association". Circulation. 2002; 97 (18): 1876-87.

[3] Bay NV, Study of production and utilization of Earth-norms (periony $\mathrm{x}$ excavates) as feed supplement in chicken production systems at farmers' level. Naong Thang Village, Vientiane, 2002; Pp. 160.

[4] Bosman RJ, Rachel PB, and Anthony F, Trajectory analysis of serum biomarker concentration facilitates outcome prediction after pediatric traumatic and hypoxemic brain injury. Dev. Neurosci. 2005; 32(5-6):396-405.

[5] Bowman WC, and Rand MI, Textbook of pharmacology (3rd Ed). London: Blackwell Scientific Pub 1985; Pp. 19431964.

[6] Cantrill JA, Diabetes Mellitus. In: Walker, R. and I. Edwards (Eds.), Clinipharmacy and Therapeutics. 2nd Edn., Churchill Livingstone, London, 1999; pp: 635-652.

[7] Chapatwala K, Boykin MA, and Rajanna B, Effects of intraperitoneally injected cadmium on renal and hepatic glycogenic enzymes in the rat. Drug.Chem.Toxicol. 1982; 5:305-317.

[8] Dhanabal SP, Raja MK, Ramanathan M, Suresh B, Hypoglycemic activity of Nymphaca stellata leaves ethnolic extract in alloxan-induced diabetic rats. Fitoterapia 2007; 78. 288-91.

[9] Egwin CE, Halima AM, and Ibrahim HO, Purification of frog oil using animal-bone activated carbon. International Journal of Emerging Technology and Advanced Engineering. 2013; ISSN 2250-2459. ISO 9001:Vol. 3, Issue 3, March 2013. 
[10] European Treaty Series, European Convention for the protection of vertebrate animals used for experimental and other scientific purposes. European Treaty Series, Strasbourg, 2005; ETS-123.

[11] Girard-Mauduit S, The lipid triad, or how to reduce residual cardiovascular risk? Annales d'Endocrinologie, 2010; Volume 71, Issue 2, pg: 89-94.

[12] Granner DK, Mayes PA, Rodwell VW, Harper's Biochemistry, $24^{\text {th }}$ ed, Connecticut, USA, Appleton and Lange. 1996; 586-587.

[13] Guyton Arthur, and John Hall John, Textbook of Medical Physiology, Saunders, September, 1996; ISBN 978-0-7.

[14] Heinz E, Plant glycolipids: structure, isolation and analysis. in Advances in Lipid Methodology - 3, 1996; pp. 211-332 (ed. W.W. Christie, Faty Press, Dundee).

[15] Hughes D, Croaking for their mates. The Country-side 1981; 1 (16). Pp.101-103.

[16] Hussain MA, and Theise ND, Stem-cell therapy for diabetes mellitus. Lancet 2004; 364:203.

[17] Kameswara RB, Renuka SP, Raja-Sekar MD, Antidiabetic activity of Terminalia pallida fruit in alloxan induced diabetic rats. J Ethnopharmacol 2003; 85: 169 - 172.

[18] King H, Aubert R, and Herman WH, Global burden of diabetes, 1995-2025 prevalence, numerical estimates and projections. Diabetes Care, 1998; 21:1414-1431.

[19] Klip A, Cellular Mechanism of Action of Metformin. Diabetes Care 1990; June; 13(6):696-704.

[20] Lands AM, and William EM, "Dietary fat and health: the evidence and the politics of prevention: careful use of dietary fats can improve life and prevent disease". Annals of the New York Academy of Sciences (Blackwell) 2005; 1055: 179-192.

[21] Larrea DH, Memorandum and frog survey in Vientiane perfective. Living Acquactic Resources Research Centre. 2001; Pp. 241-255.

[22] Lyons TJ, Lipoprotein glycation and its metabolic complications. Diabetes Care. 1992; 41(2):67-73.

[23] Malloy HT, and Evelyn KA, The determination of bilirubin with the photoelectric colorimeter. J Biol Chem, 1937; 119: 481-490.

[24] Manjunatha H, and Srinivasan K, Hypolipidemic and antioxidant potency of heat processed turmeric and red pepper in experimental Rats. Afr. J. Food Sci. 2008; 2:1-6.

[25] Mario Edwardo Santos Cabral, Diogenenes de queiroz Dias, Debora Lima Sales, Olga Paiva Oliveira,Diego Alves Teles, Jaoao Antonio de Araujo Filho, Evaluation of the antimicrobial activities and chemical composition of body fat from Amphibians Leptodactylus macrosternum MirandaRibeiro (1926) and Leptodactylus vastus Adolf Lutz (1930) in North Brazil. 2013; Evidence-Based Complementary and Alternative Medicine.

[26] Marles RJ, and Farnsworth NR, Antidiabetic plant and their active constituents. Phytomedicine, 1995; 2:137-189.

[27] McCarthy $M$, and Frognel $P$, Genetic approaches to the molecular understanding of type 2 diabetes. Am. J. Physiol.
Endocrinol. Metab., 2002; 283: E217-E225.

[28] Mooradian AD, Albert SG, Bernbaum M, Plummer S, The effect of glipizide gastrointestinal therapeutic system on islet cell hormonal responses to a meal in NIDDM. Diabetes Care; 1996; 19:883-884 (AN:(96440298).

[29] Murray M, and Pizzorno J, Encyclopedia of Natural Medicine, 2nd edition; Prima Health Publishing, Rockling, U.S.A. 1997; Pp. 401-2.

[30] Ngaha EO, Akanji MA, Madusolumuo MA, Studies on correlation between chloroquine-induced tissue damage and serum changes in rats. Experientia 1989; 45:143.

[31] Okere OS, Okoli BJ, and Adeyemo SO, Hypoglycaemic potential of Python regius fat. Research Journal in Engineering and Applied Sciences. CEmerging Academy Resources. 2013; (ISSN: 2276-8467) 2(3):192-198.

[32] Oldhan RS, Biodiversity and Hyperdiversity in Nigerian Amphibians 2000.

[33] Pirone C, and Aebi M, "Intracellular functions of N-linked glycans". Science 2009; 291(5512): 2364-69.

[34] Porter JR, and Barrett TG, Monogenic syndromes of abnormal glucose homeostasis: clinical review and relevance to the understanding of the pathology of insulin resistance and $\beta$ cell failure. J Med Gene. 2005; 42: 893-902.

[35] Rotshteyn Y, and Zito SW, Application of modified in vitro screening for identifying herbals possessing sulfonylureaslike activity. Journal of Ethnopharmacology 2004; 93: 337344.

[36] Sarah W, Gojka R, Anders G, Richard S, and Hilary K, Global prevalence of diabetes. Diabetes Care 2004; 27: 1047-1053.

[37] Shahjahan M, Sabitha KE, Mallika J, and Shyamala-Devi CS, Effect of Solanum trilobatum against carbon tetrachloride induced hepatic damage in albino rats. Indian J. Med. Res., 2004; 120: 194-198.

[38] Steward JE, The effect of periodontal treatment on glycemic control in parents with type 2 diabetes mellitus. 2002; Vol. 28 pg: 306-310.

[39] Turner RC, Cull CA, Frighi V, Holman RR, Glycaemic control with diet, sulfonylurea, metformin: Progressive requirements for multiple therapies $2005 ; 12: 281-312$.

[40] Verge CF, Gianani R, and Kawasaki E, Predicting type one diabetes in first degree relatives using a combination of insulin, GAD and ICA512bdc/1A-2 auto antibodies. Diabetes, 1996; 45: 926-933.

[41] WHO (World Health Organisation), Second report of the WHO expert committee on Diabetes mellitus. World Health Organization, Technical Report Series. 1980; 646, Geneva, pp: 66.

[42] Willis JA, Scott RS, and Brown LJ, Islet cell antibodies and antibodies against glutamic acid decarboxylase in newly diagnosed adult onset diabetes mellitus. Diabetes Res. Clin. Pract, 1996; 33: 89-97.

[43] Yamamoto H, Uchigata Y, Okamoto H, Streptozotocin and alloxan induce DNA strand breaks and poly (ADP-ribose) synthetase in pancreatic islets. Nature 1997; 294. 284-6. 